\title{
DRUG RESISTANCE IN HELICOBACTER PYLORI
}

Passos MCF. Drug resistance in Helicobacter pylori. Arq Gastroenterol. 2016;53(4):213-4.

H. pylori infection determines an important acute and chronic gastric mucosa inflammation. If untreated, the inflammation may remain forever, being infrequently spontaneously eliminated. It is known that chronic gastritis caused by this infection may lead to atrophic gastritis, intestinal metaplasia and dysplasia, thus setting the role of $H$. pylori in gastric carcinogenesis cascade ${ }^{(4,7)}$. Therefore recent meetings on the subject suggest to eradicate this organism in all infected individuals ${ }^{(2,3,8)}$. The most widely used treatment consists of an association of clarithomycin, amoxyllin and a proton pump inhibitor (PPI) during 7 days $^{(3,8)}$. However, it is noticed that the currently used treatments in order to eradicate $H$. pylori present decreasing levels of success. The Maastricht IV Consensus Report. draws attention to some factors that may commit the efficacy of the threefold scheme, such as high resistance to antibiotics, specially to clarithomycin; incomplete treatment compliance; high gastric acidity, high bacterial load and different strains of $H$. pylori ${ }^{(8)}$.

This months' edition of Archives of Gastroenterology journal publishes an excellent review paper on the resistance of $H$. pylori to antimicrobials, written by Vianna et al. ${ }^{(12)}$. The authors carried a careful and comprehensive literature review on available methods to diagnose bacterial resistance, further highlighting the current susceptibility to each of the antibiotics used to treat this infection and the main factors associated with resistance in these cases.

In fact, recent molecular studies showed high levels of $H$. pylori resistance to some antibiotics that are routinely used in eliminating schemes, especially clarithomycin and fluoroquinolones ${ }^{(7)}$. Many of these studies have shown that resistance to clarithomycin is really high in some regions of the world, directly affecting the eradication of $\mathrm{H}$. pylori. An European multicenter study comprising 18 countries showed high levels of resistance to both clarithomycin $(17.5 \%)$ and fluoroquinolones $(14.1 \%$ ), varying widely according to the regions ${ }^{(9,13)}$. For this reason, the latest Maastricht Consensus do not recommend the use of this antibiotic as first line of treatment in regions where resistance to clarithomycin rates are higher than 15\%$20 \%{ }^{(8)}$. This is the case, for example, of some regions in Italy and in Poland, where the first choice schemes no longer include the macrolide ${ }^{(1,10,13)}$.
Cell culture methods are the most used to determine the bacterial sensitivity to antibiotics. However, these procedures are seldom used with $H$. pylori, due to their slower growth and to the need of special requirements to take care of their cultivation ${ }^{(10)}$. Therefore, molecular tests conducted from gastric biopsies have been used in molecular biology laboratories, showing high levels of sensitivity and specificity ${ }^{(9)}$. The method involves extraction of bacterial ADN, amplification of genes associated with resistance and submission of the product to test strips for hybridization, enabling the display of fluorescence bands and to find the wild sequences or some mutations specified in the test $\operatorname{strip}^{(9)}$.

Vianna et al. conducted an extensive review of the major studies carried out in different regions of the world on the resistance to each antibiotic routinely used in H. pylori eradication schemes. The authors showed different results observed in studies across the US, Europe and Asia, once again highlighting the importance of local and regional determination of antimicrobial resistance ${ }^{(12)}$.

Studies carried out in Brazil between 2000 and 2014 show that the population's resistance to clarithomycin ranged from $7 \%$ to $27 \%$, varying across different regions $^{(3)}$. Resistance to amoxicillin is generally very low. Studies in our environment showed a $0.4 \%$ resistance, unlike that observed with metronidazole, for which resistance rates exceed $40 \%{ }^{(3)}$. Only one study in the country, held in the Sao Paulo region, evaluated the primary resistance to levofloxacin, finding rates of $23 \%{ }^{(6)}$.

Recently, Sanches et al. conducted the first Brazilian multicenter study for the molecular determination of primary genotypic resistance of $H$. pylori to clarithomycin and fluoroquinolones involving different regions of Brazil( ${ }^{(11)}$. The authors found an average clarithomycin resistance of $16.9 \%$ and an fluoroquinolones resistance of $13.5 \%$.

We believe that soon the molecular tests to determine and track primary genotypic resistance of H. pylori to antibiotics will be routinely performed in major centers of Brazil, thus facilitating the best antibiotic therapy choice.

Also in this edition, Dalla-Nora et al., researchers at the University of Santa Maria/RS, conducted a major study to determine the diagnostic performance of the immunochromatographic test of stool antigen aiming

* Professora Associada da Faculdade de Medicina da Universidade Federal de Minas Gerais. 
the identification of $H$. pylori infection in dyspeptic patients ${ }^{(5)}$. The stool test had $67.5 \%$ sensitivity and $85.5 \%$ specificity. The authors concluded that although this test is feasible from an economic point of view and well accepted by patients, the diagnostic accuracy observed was not satisfactory and is not recommended for the primary diagnosis of the infection.
The findings of this study are quite significant because so far few studies have been conducted in Brazil to evaluate the effectiveness of stool antigen test for initial diagnosis of H. pylori infection ${ }^{(9)}$.

Maria do Carmo Friche PASSOS *

Passos MCF. Resistência do H. pylori aos antibióticos. Arq Gastroenterol. 2016;53(4):213-4.

\section{REFERENCES}

1. Biernat MM, Poniewierka E, Błaszczuk J, Czapla L, Kempiński R, Ksiądzyna D, et al. Antimicrobial susceptibility of Helicobacter pylori isolates from Lower Silesia, Poland. Arch Med Sci. 2014;10:505-9.

2. Chey WD, Wong BC. Practice Parameters Committee of the American College of Gastroenterology. American College of Gastroenterology Guideline on the Management of Helicobacter pylori Infection. Am J Gastroenterol. 2007;102:1808-25.

3. Coelho LG, Maguinilk I, Zaterka S, Parente JM, Passos MCF, Moraes-Filho JPP. 3rdBrazilian Consensus on Helicobacter pylori. Arq Gastroenterol. 2013;50:81-96.

4. Correa P, Piazuelo MB. Natural history of Helicobacter pylori infection. Dig Liver Dis. 2008:40:490-6.

5. Dalla Nora M, Hörner R, De Carli DM, Rocha MP, Araujo AF, Fagundes RB. Is the immunocromatographic fecal antigen test effective for primary diagnosis of Helicobacter pylori infection in dyspeptic patients? Arq Gastroenterol. 2016,53:224-7.

6. Eisig JN, Silva FM, Barbuti RC, Navarro-Rodriguez T, Moraes-Filho JP, Pedrazzoli Jr J. Helicobacter pylori antibiotic resistance in Brazil: clarithromycin is still a good option. Arq Gastroenterol. 2011;48:261-4.
7. Graham DY. Helicobacter pylori Update: Gastric Cancer, Reliable Therapy, and Possible Benefits. Gastroenterology. 2015;148:719-31.

8. Malfertheiner P, Megraud F, O'Morain CA, Atherton J, Axon AT, et al. Management of Helicobacter pylori infection- The Maastricht IV/ Florence Consensus Report. Gut. 2012;61:646-64.

9. Mégraud F, Floch P, Labenz J, Lehours P. Diagnostic of Helicobacter pylori infection. Helicobacter. 2016;21(Suppl 1):8-13.

10. Rongli C, Liya Z. Helicobacter pylori infection: an overview in 2013 , focus on therapy. Chin Med J. 2014;127:568-73.

11. Sanches BF, Martins GM, Lima KS, Cota BD, Moretzshon LD, Ribeiro LT, et al. H. pylori resistence to clarithromycin and fluoroquinolones in Brazil. World J Gastroenterol. 2016: in press.

12. Vianna JS, Ramis IB, Ramos DF, Von Groll A, Silva PEA. Drug resistance in Helicobacter pylori. Arq Gastroenterol. 2016,53:215-23.

13. Zagari RM, Romano M, Ojetti V, Stockbrugger R, Gullini S, Annibale B, et al. Guidelines for the management of Helicobacter pylori infection in Italy: The III Working Group Consensus Report 2015. Dig Liver Dis. 2015;47:903-12. 